\title{
Effects of shrimp-trawling on abundance of benthic macrofauna in Gullmarsfjorden, Sweden
}

\author{
Maria Hansson $^{1, *}$, Mats Lindegarth ${ }^{2}$, Daniel Valentinsson ${ }^{1,3}$, Mats Ulmestrand ${ }^{1}$ \\ ${ }^{1}$ National Board of Fisheries, Institute of Marine Research, Box 4, 45321 Lysekil, Sweden \\ ${ }^{2}$ Centre for Research on Ecological Impacts of Coastal Cities, Marine Ecology Laboratories, A11, University of Sydney. \\ New South Wales 2006, Australia \\ ${ }^{3}$ Tjärnö Marine Biological Laboratory, 45296 Strömstad, Sweden
}

\begin{abstract}
Hypotheses about effects of shrimp-trawling on large benthic macrofauna were tested in a manipulative experiment in Gullmarsfjorden, Sweden. The experiment lasted $1.5 \mathrm{yr}$ and included 3 trawl sites and 3 control sites, each of which was sampled at 4 times before and 4 times after trawling was commenced (a total of 480 samples). Gear and intensities were chosen to approximate those before trawling was prohibited $6 \mathrm{yr}$ before the experiment. The overall trend was that biomass and abundances of animals decreased as a consequence of trawling but few taxa differed significantly among treatments. The mean abundance of echinoderms, in particular the brittlestars Amphiura sp., decreased significantly and substantially after 7 to $12 \mathrm{mo}$ of trawling. In general, however, changes in abundances of animals from one time of sampling to another, and from before to after trawling started, differed among sites. General models based on size and feeding strategy did not accurately predict differences among taxa in sensitivity to disturbances. Differences in overall impacts between this and previous experiments are discussed in terms of fishing intensity, natural variability and experimental design.
\end{abstract}

KEY WORDS: Trawling · Disturbance $\cdot$ Benthic assemblage $\cdot$ Environmental impact - Variability

\section{INTRODUCTION}

Estimates of intensity and spatial distribution of fishing effort in different parts of the world suggest that some areas of the seabed are swept several times each year by mobile fishing gear (e.g. Lindeboom 1995, Kaiser et al. 1996). Surveys using optic and sonar techniques have shown that these activities can cause serious mechanical disturbance to marine sediments (e.g. Brylinsky et al. 1994, Kaiser \& Spencer 1996, Kaiser et al. 1996, Schwinghamer et al. 1998). Consequently, trawling may cause direct mortality to benthic infauna, as well as persistent modification of the structure and topography of these habitats.

It is difficult to make general predictions about the types of impacts trawling and dredging may have on benthic fauna because gear, intensity of fishing, inten-

•E-mail: m.hansson@imr.se sity of natural disturbances and composition of assemblages differ among studies (Jones 1992, Hall 1994, Auster 1998, Kaiser 1998). Nevertheless, it is predicted that trawling, in the long term, will lead to degradation and decreased diversity of benthic habitats and organisms (Jones 1992, Auster et al. 1996, Gray 1997, Jennings \& Kaiser 1998). It is also suggested that effects of trawling vary among taxonomic groups and among animals with different life-history characteristics. Densities of large, long-lived animals living near the sediment surface, such as bivalves, echinoids and anemones, are predicted to decrease. Small, fastgrowing, regenerating and mobile animals such as polychaetes, crustaceans and ophiurids are expected to become more dominant (e.g. De Groot 1984, Rumohr \& Krost 1991, Hall 1994, Kaiser 1998, Thrush et al. 1998).

These predictions have been tested in a number of mensurative experiments (e.g. Collie et al. 1997, Thrush et al. 1998, Hill et al. 1999) and in experiments 
where the intensity of trawling or dredging has been controlled (e.g. Bergman \& Hup 1992, Thrush et al. 1995, Currie \& Parry 1996, Kaiser \& Spencer 1996, Kaiser et al. 1996, 1998, Tuck et al. 1998). While models about overall effects and relative sensitivity to trawling among different types of animals appear compelling, empirical tests have produced results that are sometimes ambiguous and inconsistent among studies. For example, the number of species in trawled areas has appeared to increase (Tuck et al. 1998) and predictions about qualitative differences in impacts among animals with different feeding types and depths of occurrence in the sediment have failed (Currie \& Parry 1996). Furthermore, impacts of trawling or dredging typically differ among places (Thrush et al. 1995, Kaiser \& Spencer 1996). This indicates that the effects of mobile fishing gear may vary in complex ways; to understand the causes of this complexity, it is necessary that experiments which account for natural spatial and temporal variability at various scales are designed (Jones 1992, Thrush et al. 1998, Lindegarth et al. 2000).

Our experiment was designed to test hypotheses about effects of trawling on assemblages of macrofauna in Gullmarsfjorden, Sweden. This fjord has supported a minor fishery for the shrimp Pandalus borealis (Kröyer) since 1902 (Andersson 1964). In January 1990 trawling was banned in the area to protect the fjord as an important reference area for scientific purposes and to protect spawning areas for fish stocks. Restrictions were, however, only temporary, and in 1995 it was decided that a large-scale experiment should be done to evaluate the consequences for benthic fauna if trawling were reintroduced into the fjord using the same gear and intensity as that used prior to 1990. In this paper, we test 2 general hypotheses of how trawling may affect benthic macrofauna. Firstly, we test the hypothesis that if we trawl repeatedly in some areas for 7 to $12 \mathrm{mo}$, abundances of animals in these areas will change differently relative to those in areas that are not trawled. Because effects of trawling may be cumulative or may vary among times for other reasons, we also test the hypothesis that effects on fauna differ among individual sampling times during trawling.

\section{MATERIALS AND METHODS}

Study area. The experiment was done during 1996-1997 in Gullmarsfjorden on the west coast of Sweden (Fig. 1). This fjord is approximately $35 \mathrm{~km}$ long with a maximum depth of $120 \mathrm{~m}$. The basin of Gullmarsfjorden is separated from the deeper parts of the Skagerrak by a sill at approximately $50 \mathrm{~m}$ depth. At depths below $50 \mathrm{~m}$ the salinity $(34 \%)$ and temperature

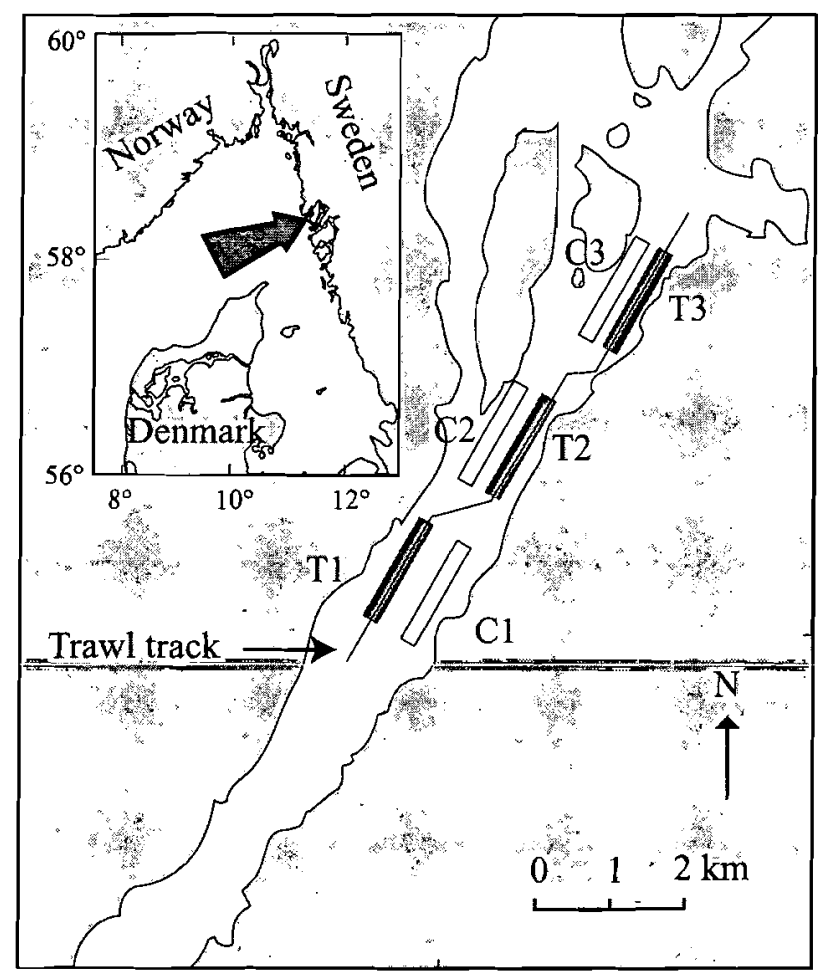

Fig. 1. Map of Gullmarsfjorden, Sweden, and the 6 experimental areas. Trawl track is marked with a line. Depth intervals: $\mathrm{C} 1,89-96 \mathrm{~m} ; \mathrm{C} 2,80-90 \mathrm{~m}$; C3, 73-79 m; T1, 79-90 m; $\mathrm{T} 2,88-93 \mathrm{~m}$ and $\mathrm{T} 3,76-81 \mathrm{~m}$

(4 to $6^{\circ} \mathrm{C}$ ) of the water is usually stable (Svansson 1984). The stagnant bottom water is normally renewed annually and oxygenated each spring.

Six sites in Gullmarsfjorden were selected for the experiment. This was the maximal number fitting in the area relevant for shrimp fishery. Each site was defined as a transect ( $1.5 \mathrm{~km}$ long) within the inner part of the fjord (Fig. 1). The depth at the sites gradually decreased from south to north of the fjord from approximately 90 to $75 \mathrm{~m}$. The bottom substrate for all sites was pure clay (Höglund 1947). Three of these sites (T1, T2 and T3) were trawled in the experiment whilst the others ( $\mathrm{C} 1, \mathrm{C} 2$ and $\mathrm{C} 3)$ remained untrawled throughout (Fig. 1).

Benthic grab-samples. Samples of benthic macrofauna were collected using a modified Smith-McIntyre grab $\left(0.1 \mathrm{~m}^{2}, 70 \mathrm{~kg}\right)$. The speed of the grab was approximately $0.5 \mathrm{~m} \mathrm{~s}^{-1}$ before closing. Each grab-sample was gently sieved on board through a $1 \mathrm{~mm}$ mesh sieve and the animals retrieved were preserved in $4 \%$ buffered formaldehyde in seawater. Macrofauna were sieved in the laboratory through $4 \mathrm{~mm}$ mesh, and fauna larger than $4 \mathrm{~mm}$ were sorted, identified to the lowest practical taxonomic level (usually species), counted, weighed (wet weight) and preserved in $80 \%$ ethanol. The use 
of this relatively coarse mesh-size allowed for a larger number of replicates to be sampled and sorted within the available resources. Furthermore, large animals are most likely to be directly damaged by trawling. For analyses, taxa were grouped according to phyla and intermediate taxonomic levels according to Hansson (1997). Benthic samples were collected at 4 times for each site from July to November 1996. Experimental trawling started in December 1996 and continued for 1 yr. Samples were again collected at 4 times during July to November 1997. At each time of sampling, 10 grab-samples were taken from randomly chosen locations at each site (resulting in a total of 480 samples). Dates for sampling were selected at random, independent of trawling.

Experimental trawling. The intensity of experimental trawling was set at a level that approximated trawling pressure before the trawl ban. Interviews with local fishermen suggested that 80 hauls per site and year was an appropriate trawling intensity. In practice this meant 2 hauls ( 1 landward and 1 seaward) once a week except during January to February 1997, when ice prevented trawling.

The design of the trawl used was consistent with regulations before trawling was banned (Fig. 2). The net was mainly constructed of $38 \mathrm{~mm}$ stretched meshes (20 mm bar length), although the square and wings were made of a larger mesh $(70 \mathrm{~mm}$ stretched). The length of the head rope was $10 \mathrm{~m}$. The ground rope was $14 \mathrm{~m}$ with about $20 \mathrm{~kg}$ of lead distributed along it. Otterboards were $140 \times 90 \mathrm{~cm}$ and each weighed $125 \mathrm{~kg}$. Trawling was done by a chartered commercial stern trawler, which was used for trawling in Gullmarsfjorden prior to the ban. The length of the vessel was $13 \mathrm{~m}$ and its engine power $240 \mathrm{hp}$. Trawling was done at speeds of 1.5 to 2 knots.

The ship was positioned using a differential global positioning system (dGPS) and trawled with an accuracy of $\pm 2.5 \mathrm{~m}$, along the same trawl track each time. Due to the great depth ( 75 to $90 \mathrm{~m}$ ), slope of the bottom and the fact that the length of the trawi wire was $300 \mathrm{~m}$, it was not possible to control exactly the position of each haul. Therefore it was also difficult to estimate the precise width of the trawled experimental sites and the average number of times that the trawl passed over any particular area. As a conservative estimate we can assume that $100 \mathrm{~m}$ was the maximal distance among hauls perpendicular to the direction of trawling. With a distance between otterboards of $30 \mathrm{~m}$, any given area within a trawled site would have been passed over by the trawl an average 24 times during the experiment.

Tests of hypotheses. Hypotheses about effects of trawling on different taxonomic groups were tested with analysis of variance (ANOVA). The linear model

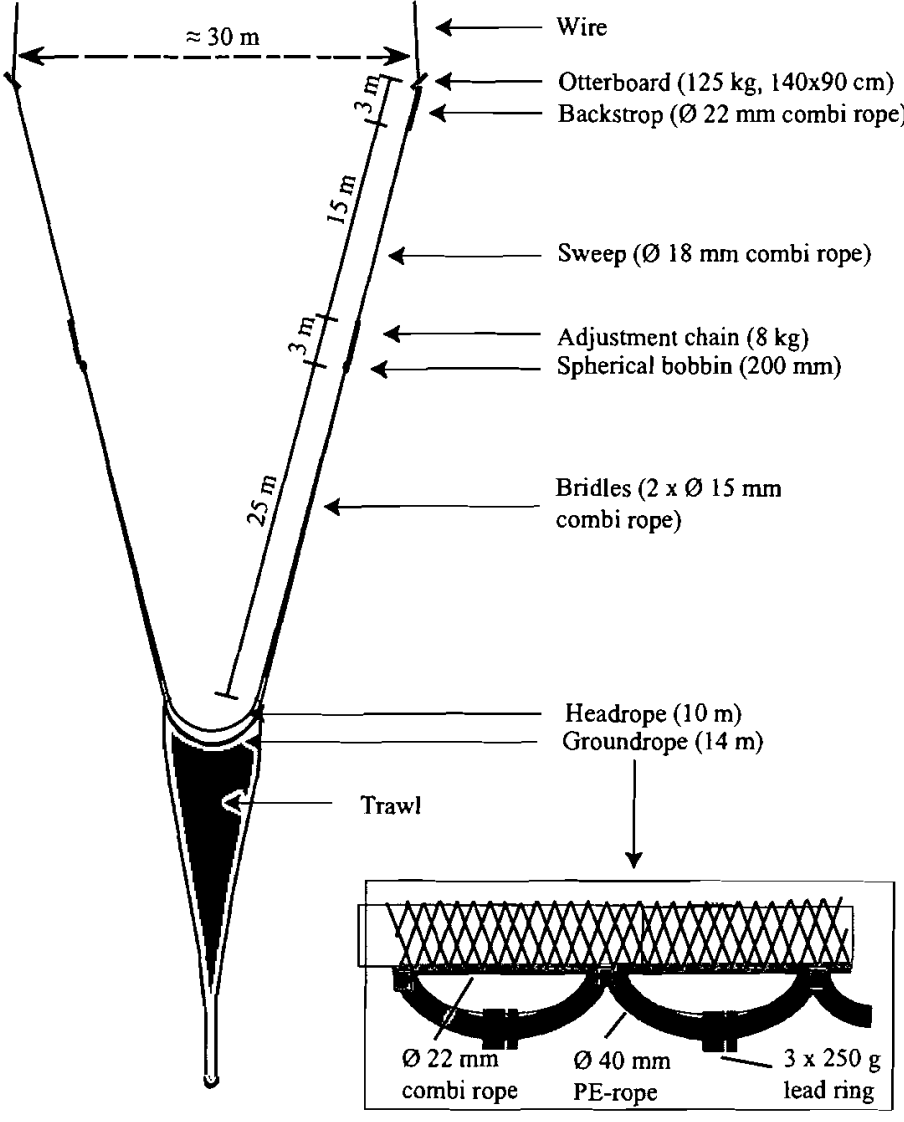

Fig. 2. Trawl rigging with bridles, bobbin, chain, sweep and backstrop. Ground rope constructed of $22 \mathrm{~mm}$ combi rope attached to the net and a $40 \mathrm{~mm}$ polyethylene (PE) rope attached with slack (in $50 \mathrm{~cm}$ bights) to the combi rope. Three lead rings, each weighing $250 \mathrm{~g}$, were mounted to each bight

for this experiment included 4 factors: 'Before versus After' (B/A; fixed); 'Trawled versus Controls' (Tr [Treatment]; fixed); 'Sites' ( $S$; random and nested within $T r$ ) and 'Times' ( $\mathrm{Ti}_{i}$ random and nested within $\mathrm{B} / \mathrm{A}$ ). Effects of trawling can be detected by testing the interactions ' $\mathrm{B} / \mathrm{A} \times \operatorname{Tr}^{\prime}$ and ' $\operatorname{Tr} \times \operatorname{Ti}(\mathrm{B} / \mathrm{A})^{\prime}$ '. The effect of the interaction ' $\mathrm{B} / \mathrm{A} \times \mathrm{Tr}^{\prime}$ can be estimated only if the variability due to either one, or both of the interactions 'B/A $\times \mathrm{S}(\operatorname{Tr})$ ' and ' $\operatorname{Tr} \times \operatorname{Ti}(\mathrm{B} / \mathrm{A})$ ' can be shown to be very small (by convention if $\mathrm{p}>0.25$; Winer et al. 1991, Underwood 1997). Post hoc-elimination and -pooling procedures were therefore applied wherever appropriate. Student-Newman-Keuls (SNK) multiple-comparison tests were used to elucidate patterns of significant differences among sites and among times.

At each time of sampling, either trawled or control sites were sampled. This design is not ideal because it can confound tests of hypotheses about short-term differences among treatments (' $\mathrm{Tr} \times \mathrm{Ti}[\mathrm{B} / \mathrm{A}]$ '). To cope with these problems, sampling dates were grouped into 4 times before and 4 times after trawling started. 
Thus, each time included 1 date of sampling for controls and 1 for trawled sites (on average $15 \mathrm{~d}$ apart). A necessary criterion for logical interpretation of effects of trawling at individual sampling times, e.g. a significant $\operatorname{Tr} \times \operatorname{Ti}(\mathrm{B} / \mathrm{A})$, is that differences between treatments did not occur before trawling was initiated. Differences in abundance of 1 taxon between trawled and control areas at times before trawling started indicate that differences may be caused by the fact that the 2 types of sites were sampled at different dates. This will, however, not affect tests of $\mathrm{B} / \mathrm{A} \times \mathrm{Tr}$ because samples at both types of sites were taken at several randomly interspersed times before and after trawling.

All analyses were done using $\log _{10}(x+1)$ transformed data. This ensures that effects are measured as relative, rather than absolute, differences among experimental treatments (e.g. Hurlbert \& White 1993). In general, this transformation also has the effect of reducing heterogeneity of variances (e.g. Underwood 1997).

\section{RESULTS}

\section{General observations}

A total of 122 species of benthic macro-fauna were identified, whilst an additional 5 were identified to genus and 8 to family levels. The polychaetes was the most diverse group ( 83 taxa) followed by crustaceans (17 taxa) and molluscs and echinoderms (13 taxa each). Approximately $80 \%$ of the total number of individuals were polychaetes, the most abundant of which was the spionid Spiophanes kroeyeri $(30 \%)$ followed by the ampharetid Melinna cristata (13\%) and the capitellid Heteromastus filiformis ( $6 \%$ ). The bivalves Abra nitida and Thyasira sp. were the most abundant molluscs. Molluscs represented. $13 \%$ of the total number of individuals, and echinoderms $7 \%$. The most abundant echinoderms were the ophiurids Amphiura filiformis and $A$. chiajei and the echinoid Echinocardium flavescens. The amphipod Eriopsa elongata was the only crustacean species among the 20 overall most abundant species.

Many species occurred in small numbers and hypotheses about effects of trawling could therefore not be tested for these taxa individually. Overall, $70 \%$ of the species were found at lower abundances in 1997 compared to the year before. For $61 \%$ of the species, abundances tended to be negatively affected by trawling, i.e. abundances had decreased more or increased less in trawled sites compared to in control sites (Table 1). This suggests a negative trend in a larger proportion of species than what is expected by chance, i.e. $50 \%$ (binomial test; $H_{0}$ : number of species
Table 1. Percent of species showing a negative trend (i.e. decreasing more or increasing less from before to after trawling) at trawled sites compared to at control sites. Probabilities were tested using a binomial (sign) test. Pair-wise comparisons between individual sites are made to evaluate spatial consistency of patterns

\begin{tabular}{|lrcl|}
\hline Comparison & No. of species & \% negative & $\mathrm{p}$ \\
\hline Trawled vs Controls & 135 & 61 & $<0.001$ \\
T1 vs C1 & 98 & 57 & $<0.05$ \\
T1 vs C2 & 96 & 60 & $<0.01$ \\
T1 vs C3 & 104 & 61 & $<0.01$ \\
T2 vs C1 & 106 & 61 & $<0.01$ \\
T2 vs C2 & 99 & 70 & $<0.001$ \\
T2 vs C3 & 107 & 61 & $<0.01$ \\
T3 vs C1 & 93 & 49 & $<0.1$ \\
T3 vs C2 & 93 & 52 & $<0.1$ \\
T3 vs C3 & 95 & 59 & $<0.01$ \\
\hline
\end{tabular}

with negative trends at trawled sites = number of species with positive trends at trawled sites). This pattern was, however, not consistent among sites (Table 1).

\section{Total number and biomass}

Total number or biomass of individuals decreased during the experiment, but no significant effects could be attributed to experimental trawling (Table 2). The total abundance of individuals decreased significantly in 2 trawled sites and 1 control site, whilst biomass decreased at all trawled sites and 1 control site (Fig. 3). The abundance and biomass of individuals at trawled sites was reduced from before to after trawling started by 25 and $60 \%$, respectively. The corresponding changes in control sites were 6 and $32 \%$.

There were also significant differences in total abundance and biomass among sampling times within individual sites, but at no time were there any significant spatially consistent differences between trawled and control sites (Table 2). The largest differences between trawled and control sites after the start of trawling was observed in the last sampling time when means for total abundance and biomass were 30 and $7 \%$ smaller respectively in trawled sites. Although these differences were not statistically significant, they were qualitatively consistent with a priori hypotheses.

Abundance of phyla. Each of the most abundant phyla showed a unique pattern of spatial and temporal variability, indicating that they responded differently to experimental trawling (Table 3). The total number of echinoderms was significantly reduced by trawling (Table 3). The number of echinoderms decreased consistently in the trawled sites, but there was no change at any of the control sites (Table 3, Fig. 4). The signifi- 
Table 2. ANOVA and SNK-tests on $\log$ (total number of individuals) and log(total biomass). Numbers in 'Error' columns refer to numbers in Column 1. $\mathrm{p}<0.05$, ns: not significant

\begin{tabular}{|c|c|c|c|c|c|c|c|c|c|}
\hline \multirow[t]{2}{*}{ No. } & \multirow[t]{2}{*}{ Source } & \multirow[t]{2}{*}{ Level } & \multirow[t]{2}{*}{ df } & \multicolumn{3}{|c|}{ Total no. } & \multicolumn{3}{|c|}{ Total biomass } \\
\hline & & & & MS & $\mathrm{p}$ & Error & MS & $\mathrm{p}$ & Error \\
\hline (1) & Before versus After (=B/A) & $a=2$ & 1 & 0.731 & - & & 4.674 & $<0.00$ & (4) \\
\hline (2) & Trawled versus Controls $(=\mathrm{Tr})$ & $\mathrm{b}=2$ & 1 & 0.535 & - & & 0.016 & $>0.90$ & (3) \\
\hline (3) & Sites $(=S(T r))$ & $c=3$ & 4 & 0.541 & $<0.00$ & (8) & 0.978 & $<0.00$ & (8) \\
\hline (4) & Times $(=\operatorname{Ti}(B / A))$ & $d=4$ & 6 & 0.169 & $<0.01$ & (8) & 0.149 & $>0.08$ & (8) \\
\hline (5) & $\mathrm{B} / \mathrm{A} \times \mathrm{Tr}$ & & 1 & 0.284 & $>0.35$ & (6) & 0.159 & $>0.14$ & $(8)+(7)+(6)$ \\
\hline (6) & $\mathrm{B} / \mathrm{A} \times \mathrm{S}(\mathrm{Tr})$ & & 4 & 0.261 & $<0.00$ & $(8)+(7)$ & 0.087 & $>0.31$ & (8) \\
\hline (7) & $\operatorname{Tr} \times \operatorname{Ti}(\mathrm{B} / \mathrm{A})$ & & 6 & 0.071 & $>0.25$ & (8) & 0.066 & $>0.48$ & (8) \\
\hline (8) & $\mathrm{S}(\mathrm{Tr}) \times \mathrm{Ti}(\mathrm{B} / \mathrm{A})$ & & 24 & 0.050 & $<0.03$ & (9) & 0.069 & $<0.04$ & (9) \\
\hline & Residual & & 432 & 0.031 & & & 0.044 & & \\
\hline \multicolumn{2}{|c|}{ Cochran's test } & & & \multicolumn{2}{|l|}{$0.162^{*}$} & & \multicolumn{2}{|l|}{$0.06 \mathrm{~ns}$} & \\
\hline \multicolumn{2}{|c|}{ SNK } & & & \multicolumn{2}{|c|}{$\mathrm{B} / \mathrm{A} \times \mathrm{S}(\mathrm{Tr})$} & & & & \\
\hline & & & & \multicolumn{2}{|c|}{$\begin{array}{c}C 1: A<B \\
C 2: A=B \\
C 3: A=B \\
S E=0.0368\end{array}$} & $\begin{array}{l}\text { T1: } A<B \\
\text { T2: } A<B \\
\text { T3: } A=B\end{array}$ & & & \\
\hline
\end{tabular}

cant decrease in the number of echinodeirms was mainly caused by a decrease in the number of brittlestars (order Ophiuridea; Table 4) and in particular the
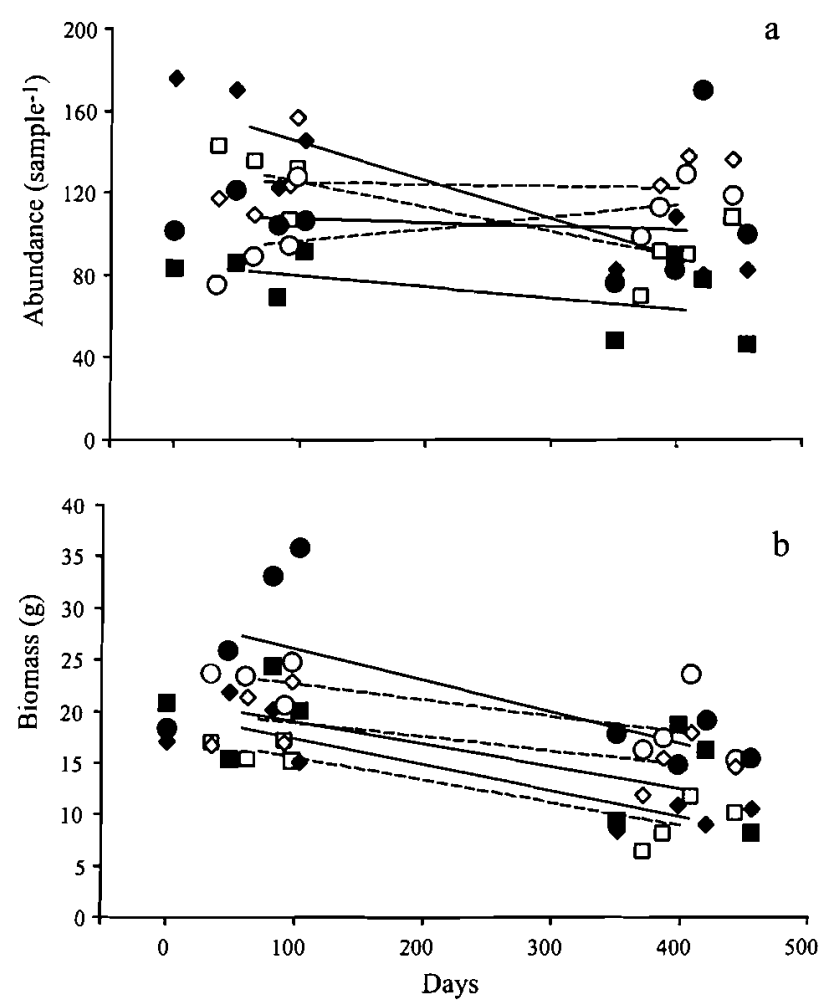

Fig. 3. Average totals for (a) the number of individuals and (b) biomass per $0.1 \mathrm{~m}^{2}$ per site and per sampling time $(\mathrm{n}=10)$. Solid symbols and solid lines represent trawled sites while empty symbols and dashed lines are control sites. Squares represent the western sites ( $\mathrm{T} 1$ and $\mathrm{C} 1$ ), diamonds represent the middle sites (T2 and $\mathrm{C} 2$ ) and circles represent the eastern sites (T3 and C3). Lines are drawn between means of samples before and after for each site species Amphiura chiajei. The number of brittlestars decreased on average by $31 \%$ at trawled sites, but as per total echinoderms, the number of brittlestars did not change at control sites. Because of significant shortterm variability, the average number of sea urchins (order Echinodea, predominantly Echinocardium flavescens and Brissopsis lyrifera) could not be tested for persistent effects of trawling (Table 4). There were, however, differences in abundance among trawled and control sites at individual times (Table 4). Because differences occurred at 1 time before and 1 time after the start of trawling, this result can, however, not be unambiguously interpreted as an effect of trawling. It may reflect the fact that, within each sampling time, trawled and control sites were not sampled simultaneously.

Although it was not possible to do an overall test of changes from before to after trawling, the total number of polychaetes did not appear to be significantly affected by trawling (Fig. 4). The number of polychaetes within individual sites decreased significantly from before to after trawling at 2 trawled sites and at 1 control site (Table 3 ). This means that the decrease at 1 control site was larger than at 1 (at least) trawled site and thus there can be no consistent difference between the 2 treatments (Fig. 4).

Despite the overall trend of decreasing numbers of polychaetes during the experiment, abundances of several families increased (Table 4). Trends of increasing abundances were found for ampharetids, scalibregmatids, maldanids, sabellids, hesionids and cirratulids, while abundances of spionids, capitellids, trichobranchids, orbinids, terebellids and nephtyids decreased during the experiment. Changes in abundances were usually qualitatively consistent between 
Table 3. ANOVA and SNK-tests of $\log _{10}(1+$ abundance $)$ of the major phyla found during the experiment. Long-term effects detected by the interaction $B / A \times \operatorname{Tr}$ and short-term effects by $\operatorname{Tr} \times \operatorname{Ti}(B / A) .{ }^{*} p<0.05,{ }^{* *} p<0.001,{ }^{*}{ }^{*} p<0.001$. nt: no test availble for hypothesis. All other error terms are identical to the error terms specified in Table 1

\begin{tabular}{|c|c|c|c|c|c|c|c|c|c|c|}
\hline \multirow[t]{2}{*}{ No. } & \multirow[t]{2}{*}{ Source } & \multirow[t]{2}{*}{$\mathrm{df}$} & \multicolumn{2}{|c|}{ Polychaetes } & \multicolumn{2}{|c|}{ Echinoderms } & \multicolumn{2}{|c|}{ Molluscs } & \multicolumn{2}{|c|}{ Crustaceans } \\
\hline & & & MS & $p$ & MS & $\mathrm{p}$ & MS & $\mathrm{p}$ & MS & $p$ \\
\hline (1) & $\mathrm{B} / \mathrm{A}$ & 1 & 1.903 & nt & 2.633 & $<0.001^{* * c c}$ & 10.222 & $<0.006^{* * c}$ & 0.148 & nt \\
\hline (2) & $\operatorname{Tr}$ & 1 & 0.403 & nt & 0.969 & $>0.822^{\mathrm{b}}$ & 4.286 & $<0.007^{* \circ b}$ & 0.012 & nt \\
\hline (3) & $\mathrm{S}(\mathrm{Tr})$ & 4 & 1.025 & $<0.000^{* * *}$ & 16.765 & $<0.000^{* * *}$ & 0.165 & $>0.411$ & 2.333 & $<0.000^{* * *}$ \\
\hline (4) & $\mathrm{Ti}(\mathrm{B} / \mathrm{A})$ & 6 & 0.124 & $>0.074$ & 0.069 & $>0.611$ & 0.612 & $<0.008^{* *}$ & 0.259 & $>0.223$ \\
\hline (5) & $\mathrm{B} / \mathrm{A} \times \mathrm{Tr}$ & 1 & 0.225 & nt & 0.481 & $<0.020^{* a}$ & 0.000 & $>0.970^{\mathrm{e}}$ & 0.030 & nt \\
\hline (6) & $\mathrm{B} / \mathrm{A} \times \mathrm{S}(\mathrm{Tr})$ & 4 & 0.373 & $<0.001^{* *}$ & 0.016 & $>0.950$ & 0.272 & $>0.181^{d}$ & 0.261 & $>0.233$ \\
\hline (7) & $\operatorname{Tr} \times \operatorname{Ti}(\mathrm{B} / \mathrm{A})$ & 6 & $0: 122$ & $>0.079$ & 0.077 & $>0.555$ & 0.075 & $>0.822$ & 0.279 & $>0.189$ \\
\hline (8) & $\mathrm{S}(\mathrm{Tr}) \times \operatorname{Ti}(\mathrm{B} / \mathrm{A})$ & 24 & 1.055 & $>0.109$ & 0.092 & $>0.167$ & 0.159 & $<0.002^{* *}$ & 0.174 & $<0.000^{\cdots *}$ \\
\hline (9) & Residual & 432 & 0.040 & & 0.071 & & 0.074 & & 0.064 & \\
\hline \multicolumn{2}{|c|}{ Cochran's test } & & \multicolumn{2}{|l|}{$0.097^{*}$} & \multicolumn{2}{|l|}{0.048} & \multicolumn{2}{|l|}{$0.070^{*}$} & 0.042 & \\
\hline \multirow[t]{2}{*}{ SNK } & & $=-$ & \multicolumn{2}{|c|}{$\mathrm{B} / \mathrm{A} \times \mathrm{S}(\mathrm{Tr})$} & \multicolumn{2}{|c|}{$\mathrm{B} / \mathrm{A} \times \mathrm{Tr}$} & \multirow{2}{*}{\multicolumn{2}{|c|}{$=$}} & & \\
\hline & & & \multicolumn{2}{|c|}{$\begin{array}{c}\mathrm{C} 1: \mathrm{A}<\mathrm{B} ; \mathrm{T} 1: \mathrm{A}<\mathrm{B} \\
\mathrm{C} 2: \mathrm{A}=\mathrm{B} ; \mathrm{T} 2: \mathrm{A}<\mathrm{B} \\
\mathrm{C} 3: \mathrm{A}=\mathrm{B} ; \mathrm{T} 3: \mathrm{A}=\mathrm{B} \\
\mathrm{SE}=0.037\end{array}$} & \multicolumn{2}{|c|}{$\begin{array}{c}\mathrm{C}: \mathrm{A}=\mathrm{B} \\
\mathrm{T}: \mathrm{A}<\mathrm{B} \\
\mathrm{SE}=0.048\end{array}$} & & & & \\
\hline \multicolumn{7}{|c|}{ Error terms after elimination and pooling: ${ }^{a}(8)+(7)+(6){ }_{i}^{b}(3) ;{ }^{c}(4) ;{ }^{d}(8)+(7) ;{ }^{e}(6)$} & & & & \\
\hline
\end{tabular}

treatments (Table 4). Only for the owenids did patterns of temporal change differ qualitatively among control and trawled sites (Table 4). The change in abundance, from before to after trawling started, differed significantly among sites within treatments for approxi- mately $50 \%$ of the polychaete families (Table 4). Furthermore, abundances differed consistently between trawled and control sites at several times of sampling for capitellids (mainly Heteromastus filiformis) and owenids (mainly Myriochele oculata) (Table 4). As for

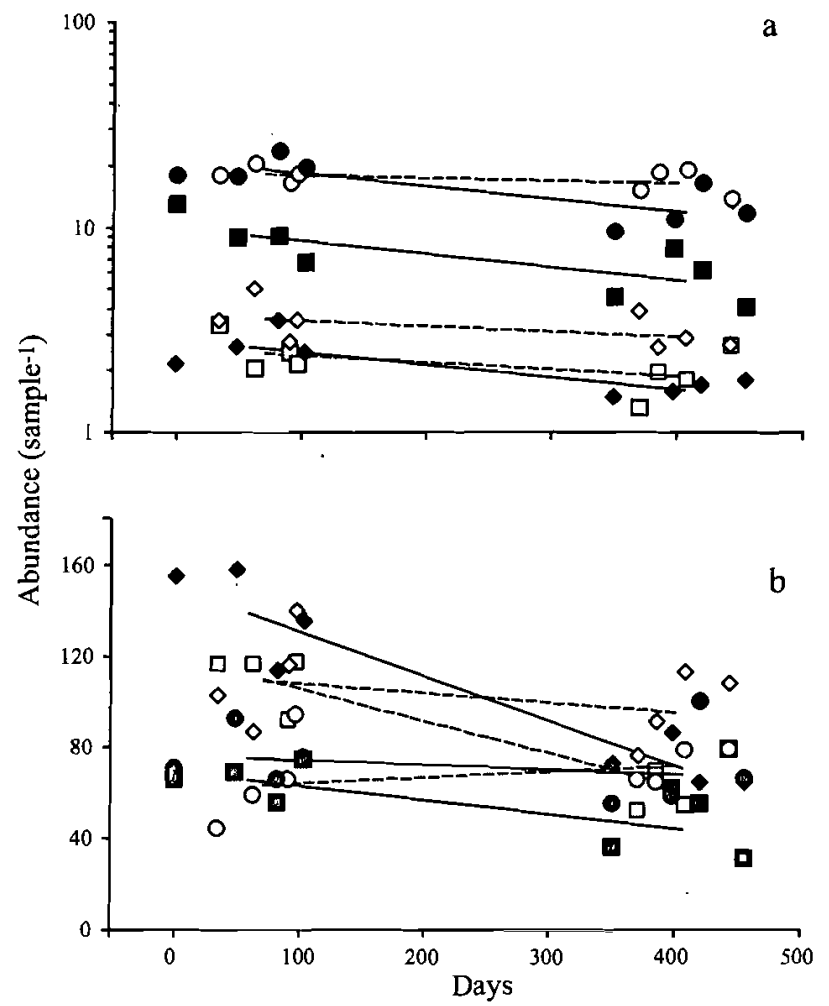

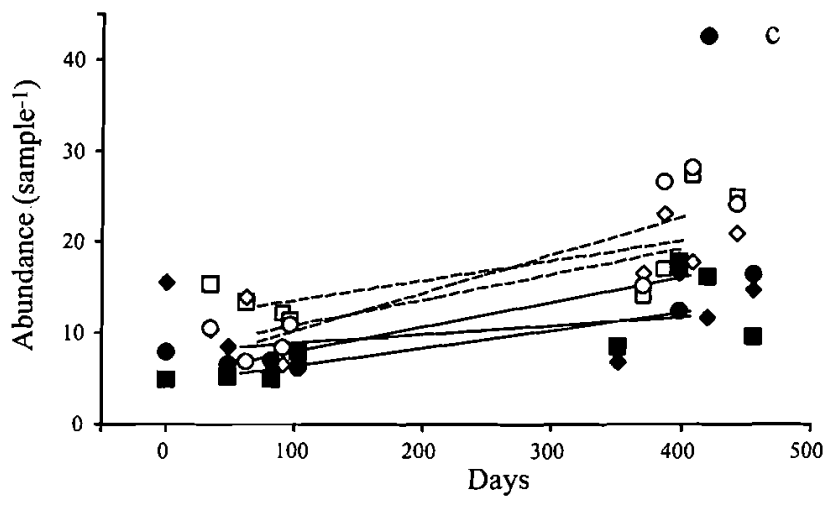

Fig. 4. Number of (a) echinoderms (using a logarithmic scale), (b) polychaetes and (c) molluscs per $0.1 \mathrm{~m}^{2}$. Symbols and lines are as in Fig. 2 
Table 4. Summary for tests of hypotheses of spatial and temporal dynamics for groups of annelids, echinoderms, molluscs and crustaceans. Level of significance shown for tests of hypotheses of effects of trawling. All analyses are done on $\log _{10}(x+1)$ transformed original data. $" p<0.05,{ }^{*} p<0.01,{ }^{* *} p<0.001$. nt: no test available, ns: not significant at 0.05 level

\begin{tabular}{|c|c|c|c|c|c|c|c|}
\hline Taxon & $\begin{array}{l}\text { Pre-trawling } \\
\text { mean }\end{array}$ & $\begin{array}{c}\% \mathrm{ch} \\
\mathrm{C}\end{array}$ & $\underset{T}{\text { ange }}$ & $\begin{array}{c}\mathrm{B} / \mathrm{A}^{*} \\
\mathrm{Tr}\end{array}$ & $\begin{array}{l}\mathrm{B} / \mathrm{A}^{*} \\
\mathrm{~S}(\mathrm{Tr})\end{array}$ & $\begin{array}{c}\mathrm{Tr}^{*} \\
\operatorname{Ti}(B / A)\end{array}$ & $\begin{array}{l}\mathrm{S}(\mathrm{Tr})^{*} \\
\operatorname{Ti}(\mathrm{B} / \mathrm{A})\end{array}$ \\
\hline \multicolumn{8}{|l|}{ Annelid family } \\
\hline Spionidae & 46 & -18 & -34 & $>0.67^{\mathrm{a}}$ & *** & $>0.40^{d}$ & ns \\
\hline Ampharetidae & 26 & 6 & 9 & $>0.80^{\mathrm{a}}$ & . & $>0.15^{\mathrm{d}}$ & ns \\
\hline Capitellidae & 11 & -71 & -62 & $>0.93^{b}$ & ns & $<0.001^{c}$ & $\ldots$ \\
\hline Scalibregmatidae & 1.5 & 168 & 109 & $>0.75^{\mathrm{a}}$ & $\cdots$ & $>0.79^{c}$ & $\cdots$ \\
\hline Trichobranchidae & 3.6 & -35 & -31 & $>0.77^{\mathrm{a}}$ & $\cdots$ & $>0.71^{\mathrm{c}}$ & ns \\
\hline Oweniidae & 2.4 & 127 & -43 & nt & ns & $<0.01^{\mathrm{c}}$ & $\cdots$ \\
\hline Maldanidae & 1.1 & 114 & 23 & $>0.24^{\mathrm{e}}$ & ns & $>0.48^{\mathrm{c}}$ & ns \\
\hline Sabellidae & 0.4 & 740 & 308 & $>0.23^{\mathrm{a}}$ & • & $>0.29^{c}$ & $\cdots$ \\
\hline Hesionidae & 0.8 & 55 & 23 & $>0.41^{\mathrm{e}}$ & ns & $>0.65^{c}$ & ... \\
\hline Orbinidae & 1.1 & -23 & -24 & $>0.92^{\mathrm{a}}$ & $\cdots$ & $>0.65^{\mathrm{d}}$ & ns \\
\hline Terebellidae & 1.2 & -28 & -62 & $>0.78^{a}$ & *. & $>0.59^{c}$ & $\cdot$ \\
\hline Cirratulidae & 0.7 & 25 & 29 & $>0.78^{a}$ & ns & $>0.48^{c}$ & *. \\
\hline Nephtyidae & 0.9 & -48 & -43 & $>0.84^{\mathrm{d}}$ & ns & $n \mathbf{s}^{\mathrm{d}}$ & ns \\
\hline \multicolumn{8}{|l|}{ Echinoderm order } \\
\hline Echinoidea & 2.6 & -53 & -57 & nt & ns & $<0.02^{\mathrm{d}}$ & ns \\
\hline Ophiuriea & 6.9 & 2 & -31 & $<0.048^{e}$ & ns & $>0.64^{\mathrm{c}}$ & ns \\
\hline \multicolumn{8}{|l|}{ Mollusc family } \\
\hline Nuculidae & 2.6 & 84 & 153 & $>0.30^{e}$ & ns & $>0.76^{c}$ & $\cdots$ \\
\hline Tellinidae & 3.5 & 124 & 203 & $>0.65^{a}$ & $\cdots$ & $>0.49^{c}$ & ns \\
\hline Thyasiridae & 2.6 & 137 & 239 & $>0.77^{a}$ & ns & $>0.87^{\mathrm{c}}$ & $*$ \\
\hline \multicolumn{8}{|c|}{ Crustacean suborder } \\
\hline Amphipoda & 1.4 & 47 & 60 & $>0.87^{a}$ & ns & $>0.49^{c}$ & $\cdots$ \\
\hline \multicolumn{8}{|c|}{ Error terms: ${ }^{a}(6) ;{ }^{b}(7) ;{ }^{c}(8) ;{ }^{d}(8)+(9) ;{ }^{e}(6)+(7)+(8)$} \\
\hline
\end{tabular}

echinoids, however, differences between trawled and control sites were as common before as after experimental trawling started. Thus, again these differences cannot be unambiguously interpreted as effects of trawling.

The total abundance of molluscs increased significantly during the course of the experiment at all control sites and at 1 trawled site (Table 3, Fig. 4). There were, however, no differences between trawled and control sites in either temporal change from before to after trawling or in average abundances at single times. The total number of molluscs was largely made up of 3 families of bivalves, Tellinidae (mainly Abra nitida, Thyasiridae and Nuculidae (mainly Nucula tenuis). These types of bivalves tended to increase in abundance from before to after trawling started, but as for the total abundance of molluscs, there were no significant differences between experimental treatments (Table 4).

Finally, crustaceans, mainly the amphipod Eriopsa elongata, did not show any effects of trawling (Table 3 ). In general, the abundance of amphipods, and thus crustaceans as a whole, varied strongly among times of sampling but there were no differences in temporal variability among trawled and control sites.

\section{DISCUSSION}

Although taxa in general appeared to be negatively affected, few individual variables were consistently and significantly affected by trawling. Nevertheless, abundance of echinoderms in general, and more specifically the abundance of ophiurids, were significantly affected by trawling. Abundances of ophiurids decreased by an average of $30 \%$ at trawled sites whilst abundances at control sites did not change. Differences in abundance between trawled and control sites were also observed for individual sampling times for echinoids and for capitellid and owenid polychaetes. Because abundances of these taxa differed between treatments at individual times of sampling before trawling started, these differences can not be unambiguously attributed to trawling.

The observation that there were negative effects of trawling on echinoderms is in general agreement with previous predictions (e.g. De Groot 1984, Bergman \& Hup 1992, Thrush et al. 1998). It is, however, more surprising that the effects on echinoderms could mainly be explained by effects on ophiuroids. Ophiuroids have been suggested to be resistant to, or even favoured by, trawling because of their capacity to regenerate lost body parts and because of decreased predation by fish (North Sea Task Force 1993, Lindley et al. 1995, Kaiser \& Spencer 1996, Tuck et al. 1998). The observed decrease $(57 \%)$ in densities of echinoids at trawled sites was more consistent with predictions. The decreased densities observed at untrawled sites $(53 \%)$, however, indicate that the mortality caused by trawling did not contribute significantly to the total mortality and that it was small compared to mortality due to other causes. It is possible that the large effect on ophiuroids may be partly explained by particular behavioural responses to oxygen stress. Individuals of Amphiura sp. move from its protection in the sediment to a more exposed position on the surface as a response to sub-lethal hypoxia (Rosenberg et al. 1991). Such behaviour may have been induced by the absence of water renewal in the deep parts of the fjord in 1997. Oxygen saturation did not get below $10 \%$, which is the critical level for survival for the large majority of benthic fauna in this area (Nilsson \& Rosenberg 1994).

It is generally predicted that physical disturbance will lead to a decrease in species with a large body 
size, while small, opportunistic species will become relatively more dominant. To investigate this, we calculated and.ranked the mean body weights (as an index of size) and effect sizes for the most abundant taxa (Table 4). The size of effects was calculated as difference in percent change between trawled and control sites. A low rank, i.e. a large negative effect of trawling in comparison to other taxa, can result from a decrease in trawled sites (e.g. Terebellidae) or an increase which is smaller than at control sites (e.g. Sabellidae). We predicted that, if body size had a large influence on the size of effects, there would be a negative relationship between the ranks of body size and the effects of trawling. Within the observed range of body weights, there was, however, no clear relationship (Fig. 5). Although, weights ranged over almost 3 orders of magnitude $(0.007$ to $3.7 \mathrm{~g})$, these results need to be interpreted with caution, as the smallest components of macrofauna were not included in this study.

This analysis of size of effects does not account for any small-scale spatial or temporal variability. Such variability must be incorporated to evaluate if a certain group was significantly affected by trawling. Therefore, the significant effect observed for the ophiurids is compatible with the fact that this group does not appear to be the most negatively affected (Fig. 5). Analysis of relative size of effects can, however, be used to evaluate qualitative predictions about how effects of trawling may differ among different groups of animals. Assemblages were generally dominated by deposit

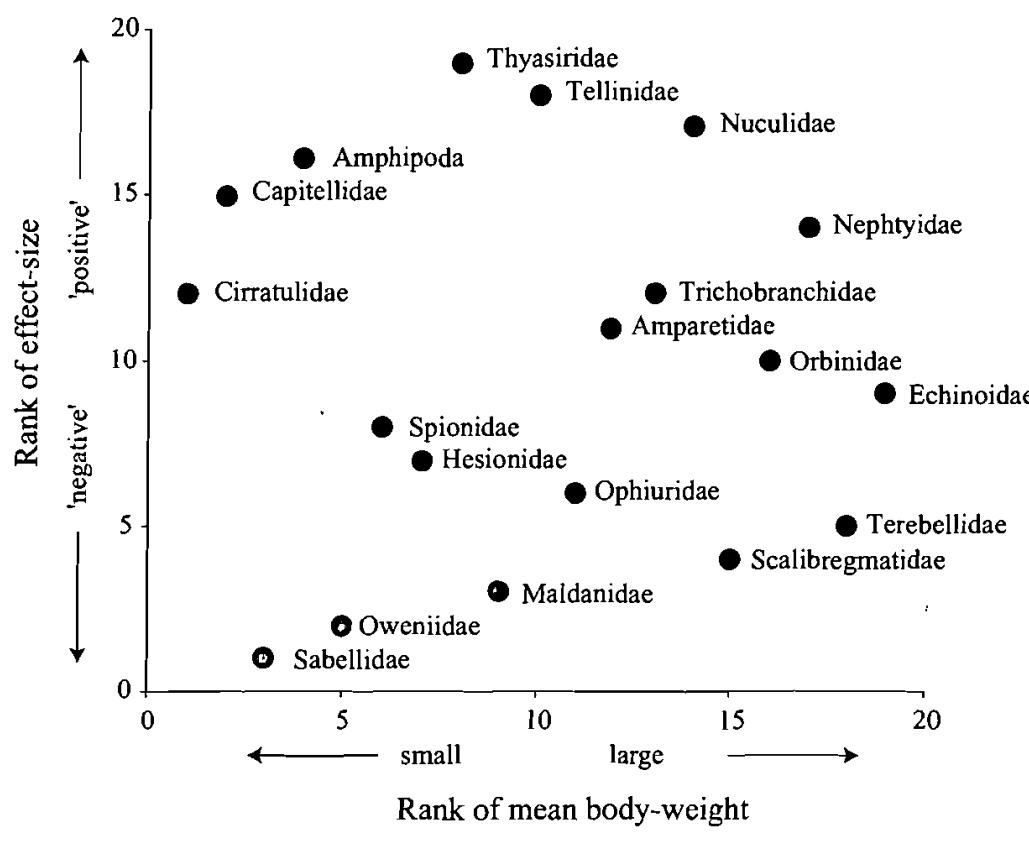

Fig. 5. Relationship between ranked average body weight and size of effects. Smaller rank indicates smaller body size and negative effects on abundance (relative to other taxa) feeders ( $90 \%$ of the individuals). These showed qualitatively mixed responses to trawling (Table 4). Interestingly, the only group of suspension feeders, the sabellids, appeared to be the taxa most negatively affected. Responses in groups containing predatory species (Hesionidae and Nephtyidae) did not deviate in any obvious way from groups with different feeding strategies (Fig. 5). Furthermore, this analysis does not appear to support the hypothesis that the ratio between molluscs and polychaetes will decrease as consequence of trawling (e.g. Thrush et al. 1998). If anything, the molluscs were among the taxa least likely to have been negatively affected by trawling in this study (Fig. 5). In summary, the observed differences among groups of echinoderms and among groups of different body size and feeding type illustrate the difficulties in predicting relative sensitivity to trawling among types of organisms.

These results differ from results of most other manipulative experiments on the effects of trawling and dredging, in the sense that fewer taxa appear to be significantly affected by trawling (e.g. Bergman \& Hup 1992, Thrush et al. 1995, Currie \& Parry 1996, Kaiser \& Spencer 1996, Kaiser et al. 1996, Tuck et al. 1998, but see Brylinsky et al. 1994). These differences can be interpreted in different ways: (1) effects of trawling vary greatly among experiments and results from previous experiments and this experiment reflects this variability, (2) this experiment underestimates the number of taxa that are affected by trawling or (3) previous experiments have overestimated the number of taxa affected by trawling.

The perceived effects of fishing disturbances may differ among experiments, either because experimental treatments differ or because the sensitivity to physical disturbance differs among assemblages. For example, each experiment has a unique combination of frequency, duration and intensity of experimental disturbance, which is dictated by the experiment's purpose. We applied a longterm disturbance using an otter-trawl to mimic a particular type of fishery. These trawls may cause smaller disturbances thạn other types of mobile fishing gear such as beam-trawls and scallop-dredges (Kaiser et al. 1996). Furthermore, other experiments have applied intense shortterm disturbances and examined their effects hours or days after the disturbance (e.g. Bergman \& Hup 1992, Kaiser \& Spencer 1996, Kaiser et al. 1996). Nevertheless, in an experiment done at similar spatial and temporal scales as the present 
one, Currie \& Parry (1996) found that of the 10 most abundant species, 6 species decreased and 1 species increased in abundance as a result of trawling. Another experiment with similar gear and intensity of trawling reported an increase in the total abundance of individuals, and of the 20 most abundant species, 5 increased and 6 decreased significantly as a consequence of trawling (Tuck et al. 1998).

Previous comparisons have shown that effects of fishing disturbance often differ among places (e.g. Thrush et al. 1995, Currie \& Parry 1996, Kaiser \& Spencer 1996). Differences in intensity of natural physical disturbances have been proposed as a model to explain differences in effects of trawling and dredging within and among studies (e.g. Kaiser 1998). From such models it is predicted that effects of human disturbance will be greater in areas with little natural disturbance. Although many natural processes may cause physical disturbances (Hall 1994), the intensity of such disturbances is likely to decrease with increasing depth. Because this experiment was done at a great depth and in muddy sediments, it is not likely that greater levels of physical disturbance can explain why fewer taxa appear to be affected in this experiment compared to many others. Another possibility is, however, that changes in oxygen conditions in the deep parts of the fjord cause repeated disturbances to assemblages in these types of habitats (e.g. Nilsson \& Rosenberg 1997). By changing age- and size-structure of assemblages, such disturbances may create assemblages which are also comparatively tolerant to physical disturbances.

Retaining statistical null-hypotheses of no effect of trawling is not alone sufficient evidence for the conclusion that trawling did not have important ecological consequences in this experiment. It is theoretically possible that a large number of taxa were affected by trawling, but the sampling effort was not sufficient to detect these effects (Eberhardt \& Thomas 1991, Fairweather 1991, Underwood 1997). To interpret these results reliably, it is necessary to inspect estimates of changes in mean abundances and to analyse patterns of temporal and spatial variability. Using the estimated means as an alternative to the null of no difference between treatments, it is possible to do a posteriori calculations of power for the ANOVA. In this way we can evaluate effects on statistical power if a larger number of sites were used in the experiment. Assuming that estimated means reflect 'true' differences between treatments, the probabilities of detecting these differences were low for the total number of individuals, total biomass and abundance of each major phylum except the echinoderms (power $<0.1$, Table 5). Even total biomass, which was the variable showing the largest effect (non-centrality parameter, $\phi=0.75$ ), can be characterised as a 'small' (size effect $f=0.75 / 120$, Cohen 1988). Furthermore, the power of these tests would not have been substantially improved even if it had been possible to include more sites in the experiment. For none of these variables would the power to detect differences between trawled and control sites have exceeded 0.3 even if all interactions except 'B/A $\times \mathrm{Tr}^{\prime}$ were pooled (Table 5). This would have been equivalent to having 17 sites of each treatment in the experiment. Thus, difference among sites in the way abundances changed from before to after trawling rather than a small number of sites was the main reason for lack of power.

In contrast to previous experiments with similar spatial and temporal scope, the design of this experiment included replicated trawled and control areas (Currie \& Parry 1996, Tuck et al. 1998). Experiments without replication at the appropriate spatial scale run the risk of overestimating effects of physical disturbance. This is because the effects of the experimental manipulation are confounded with purely spatial variability (e.g. Hurlbert 1984, Underwood 1991, 1992, Osenberg \& Schmitt 1996). If such an experimental design had been chosen for this experiment, the number of species

Table 5. Power for detecting estimated effect sizes for the interaction $\mathrm{B} / \mathrm{A} \times \mathrm{Tr}$ for total abundance, biomass and abundances. Means for trawled and control areas, before and after are shown for $\log _{10}$ transformed (untransformed data) and error mean square, non-centrality parameter $(\phi)$ and power for (a) nominal tests and (b) tests using a pooled error term. ${ }^{\text {nt }}$ No test originally available, power calculated using $\mathrm{B} / \mathrm{A} \times \mathrm{S}(\mathrm{Tr})$ as error term

\begin{tabular}{|c|c|c|c|c|c|c|c|c|c|}
\hline \multirow[t]{2}{*}{ Taxon } & \multirow[t]{2}{*}{$\operatorname{Tr}$} & \multirow[t]{2}{*}{ B } & \multirow[t]{2}{*}{ A } & \multirow{2}{*}{$\overline{\mathrm{MS}}$} & \multicolumn{2}{|l|}{$-(a)-$} & \multirow{2}{*}{$\overline{\mathrm{MS}}$} & \multicolumn{2}{|c|}{- (b) - } \\
\hline & & & & & $\phi^{*}$ & $\mathrm{p}$ & & $\phi$ & $\mathrm{p}$ \\
\hline Total number & $\begin{array}{l}\mathrm{C} \\
\mathrm{T}\end{array}$ & $\begin{array}{l}2.06(115) \\
2.04(111)\end{array}$ & $\begin{array}{l}2.03(108) \\
1.93(83)\end{array}$ & 0.26 & 0.52 & $<0.1$ & 0.08 & 0.95 & $<0.3$ \\
\hline Total biomass & $\begin{array}{l}\mathrm{C} \\
\mathrm{T}\end{array}$ & $\begin{array}{l}1.29(19) \\
1.34(22)\end{array}$ & $\begin{array}{l}1.13(13) \\
0.96(9)\end{array}$ & - & - & - & 0.07 & 0.75 & $<0.3$ \\
\hline Crustaceans $^{\text {nt }}$ & $\begin{array}{l}\mathrm{C} \\
\mathrm{T}\end{array}$ & $\begin{array}{l}0.38(2.4) \\
0.37(2.3)\end{array}$ & $\begin{array}{l}0.40(2.5) \\
0.42(2.7)\end{array}$ & 0.26 & 0.17 & $<0.1$ & 0.20 & 0.19 & $<0.1$ \\
\hline Molluscs & $\begin{array}{l}\mathrm{C} \\
\mathrm{T}\end{array}$ & $\begin{array}{l}1.02(11) \\
0.84(7)\end{array}$ & $\begin{array}{l}1.32(21) \\
1.13(13)\end{array}$ & 0.27 & 0.02 & $<0.1$ & 0.16 & 0.03 & $<0.1$ \\
\hline Polycheates $^{\text {nt }}$ & $\begin{array}{l}\mathrm{C} \\
\mathrm{T}\end{array}$ & $\begin{array}{l}1.96(91) \\
1.95(88)\end{array}$ & $\begin{array}{l}1.88(76) \\
1.78(60)\end{array}$ & 0.37 & 0.39 & $<0.1$ & 0.11 & 0.73 & $<0.3$ \\
\hline
\end{tabular}


affected by trawling would have been highly exaggerated and quantitative and qualitative estimates of effects on individual species would have been very unreliable (Lindegarth et al. 2000). Such interpretations may be consistent with precautionary principles but will not lead to a better understanding of how and to what extent mobile fishing gear affect benthic assemblages.

In summary, this experiment demonstrated a $30 \%$ decrease in the number of brittlestars. For most species natural spatial variability was larger than effects due to disturbance by trawling. For purposes of management, however, it is important to realise that a projection of the observed effect-size on brittlestars leads to a $75 \%$ reduction in 4 yr. Thus, if trawling is reintroduced at intensities similar to those used in this experiment, results indicate that serious damage will be caused to populations of one of the most conspicuous types of organisms in these habitats.

Acknowledgements. Thanks are due to the crew on 'Littorina', Sixten Söderberg and Jan Olofsson for excellent cooperation and assistance during the trips. We also thank Annika Lindahl, Katja Nagel, Katja Ringdahl and Tor Carlsson for technical assistance. We thank 3 anonymous referees for helpful comments. Earlier drafts of the manuscript were improved by comments from M. Hoskin, V. Øresland and A. J. Underwood. This study was funded by EU's Financial Instrument for Fisheries Guidance (FIFG), the Nordic Council of Ministeries, County Administration of Västra Götaland, IMR Lysekil and the Centre for Research on Ecological Impacts of Coastal Cities, University of Sydney, Australia. For further details about the data contact M.H.

\section{LITERATURE CITED}

Andersson KA (1964) Fiskar och fiske i norden. Bokförlaget Natur och Kultur, Stockholm (in Swedish)

Auster PJ (1998) A conceptual model of the impacts of fishing gear on the integrity of fish habitats. Conserv Ecol Ser 12: 1198-1203

Auster PJ, Malatesta RJ, Langton RW, Watling L, Valentine PC, Donaldson CL, Langton EW, Shepard AN, Babb IG (1996) The impacts of mobile fishing gear on seafloor habitats in the Gulf of Maine (Northwest Atlantic): implications for conservation of fish populations. Rev Fish Sci 4: 185-202

Bergman MJN, Hup M (1992) Direct effects of beam trawling on macrofauna in a sandy sediment in the southern North Sea. ICES J Mar Sci 49:5-11

Brylinsky M, Gibson J, Gordon DC Jr (1994) Impacts of flounder trawls on the intertidal habitat and community of the Minas Basin Bay of Fundy. Can J Fish Aquat Sci 51: $650-661$

Cohen J (1988) Statistical power analyses for the behavioral science. Lawrence Erlbaum Associates Inc Publishers, Hillsdale

Collie JS, Escanero GA, Valentine PC (1997) Effects of bottom fishing on the benthic megafauna of Georges Bank. Mar Ecol Prog Ser 155:159-172

Currie DR, Parry GD (1996) Effects of scallop dredging on a soft sediment community: a large-scale experimental study. Mar Ecol Prog Ser 134:131-150

De Groot SJ (1984) The impact of bottom trawling on benthic fauna of the North Sea. Ocean Manage 9:177-190

Eberhardt LL, Thomas JM (1991) Designing environmental field studies. Ecol Monogr 61:53-73

Fairweather PG (1991) Statistical power and design requirements for environmental monitoring. Aust J Freshw Res 42:555-567

Gray JS (1997) Marine biodiversity: patterns, threats and conservation needs. Biodivers Conserv 6:153-175

Hall SJ (1994) Physical disturbance and marine benthic communities: life in unconsolidated sediments. Oceanogr Mar Biol Annu Rev 32:179-239

Hansson HG (1997) NEAT (North East Atlantic Taxa): south Scandinavian marine check-list (accessed: May 1997); available at $\mathrm{http}: / / \mathrm{www} . \mathrm{tmbl}$.gu.se

Hill AS, Veale LO, Pennington D, Whyte SG, Brand AR, Hartnoll RG (1999) Changes in Irish Sea benthos: possible effects of 40 vears of dredging. Estuar Coast Shelf Sci 48:739-750

Höglund $\mathrm{H}$ (1947) Foraminifera in the Gullmar Fjord and the Skagerrak. Zool Bidr Upps 26:1-328

Hurlbert SH (1984) Pseudoreplication and the design of ecological field experiments. Ecol Monogr 54:187-211

Hurlbert SH, White MD (1993) Experiments with freshwater invertebrate zooplanktivores: quality of statistical analyses. Bull Mar Sci 53:128-153

Jennings S, Kaiser MJ (1998) The effects of fishing on marine ecosystems. Adv Mar Biol 14:201-352

Jones JB (1992) Environmental impact of trawling on the seabed: a review. NZ J Mar Freshw Res 26:59-67

Kaiser MJ (1998) Significance of bottom-fishing disturbance. Conserv Biol 12:1230-1235

Kaiser MJ, Spencer BE (1996) The effects of beam-trawl disturbance on infaunal communities in different habitats. $\mathrm{J}$ Anim Ecol 65:348-358

Kaiser MJ, Hill AS, Ramsay K, Spencer BE, Brand AR, Veale LO, Prudden K, Rees EIS, Munday BW, Ball B, Hawkins S.J (1996) Benthic disturbance by fishing gear in the Irish Sea: a comparison of beam trawling and scallop dredging. Aquat Conserv 6:269-285

Kaiser MJ, Edwards DB, Armstrong PJ, Radford K, Lough NE, Flatt RP, Jones HD (1998) Changes in megafaunal benthic communities in different habitats after trawling disturbance. ICES J Mar Sci 55:353-361

Lindeboom HJ (1995) Protected areas in the North Sea: an absolute need for future marine research. Helgol Meeresunters 49:591-602

Lindegarth $M$, Valentinsson $D$, Hansson $M$, Ulmestrand $M$ (2000) Interpreting large-scale experiments on effects of trawling on benthic fauna: an empirical test of the potential effects of spatial confounding in experiments without replicated control and trawled areas. J Exp Mar Biol Ecol 245:155-169

Lindley JA, Gamble JC, Hunt HG (1995) A change in the zooplankton of the central North Sea $\left(55^{\circ}\right.$ to $\left.58^{\circ} \mathrm{N}\right)$ : a possible consequence of changes in the benthos. Mar Ecol Prog Ser 119:299-303

Nilsson HC, Rosenberg R (1994) Hypoxic responses of two marine benthic communities. Mar Ecol Prog Ser 115: 209-217

Nilsson HC, Rosenberg R (1997) Benthic habitat quality assessment of an oxygen stressed fjord by surface and sediment profile images. J Mar Syst 11:249-264

North Sea Task Force (1993) North Sea quality status report 1993. Oslo and Paris Commissions, Olsen \& Olsen, Fredensborg 
Osenberg CW, Schmitt RJ (1996) Detecting ecological impacts caused by human activities. In: Schmitt RJ, Osenberg CW (eds) Detecting ecological impacts: concepts and applications in coastal habitats. Academic Press, San Diego, p 3-16

Rosenberg R, Hellman B, Johansson B (1991) Hypoxic tolerance of marine benthic fauna. Mar Ecol Prog Ser 79:127-131

Rumohr H, Krost P (1991) Experimental evidence of damage to benthos by bottom trawling with special reference to Arctica islandica. Meeresforsch Rep Mar Res 33(4):340-345

Schwinghamer P, Gordon DC Jr, Rowell TW, Prena J, McKeown DL, Sonnichsen G, Guignes JY (1998) Effects of experimental otter trawling on surficial sediment properties of a sany-bottom ecosystem on the Grand Banks of Newfoundland. Conserv Biol 12:1215-1222

Svansson A (1984) Hydrography of the Gullmarsfjord. Medd Havsfiskelab Lysekil Nr 297

Thrush SF, Hewitt JE, Cummings VJ, Dayton PK (1995) The impact of habitat disturbance by scallop dredging on marine benthic communities: what can be predicted from the results of experiments? Mar Ecol Prog Ser 129:141-150

Editorial responsibility: Antony Underwood (Contributing Editor), Sydney, New South Wales, Australia
Thrush SF, Hewitt JE, Cummings VJ, Dayton PK, Cryer M, Turner SJ, Funnel GA, Budd RG, Milburn CJ, Wilkinson MR (1998) Disturbance of the marine benthic habitat by commercial fishing: impacts at the scale of the fishery. Ecol Appl 8:866-879

Tuck ID, Hall SJ, Robertson MR, Armstrong E, Basford DJ (1998) Effects of physical trawling disturbance in a previously unfished sheltered Scottish sea loch. Mar Ecol Prog Ser 162:227-242

Underwood AJ (1991) Beyond BACI: experimental designs for detecting human environmental impacts on temporal variations in natural populations. Aust J Freshw Res 42: 569-587

Underwood AJ (1992) Beyond BACI: the detection of environmental impacts on populations in the real but variable world. J Exp Mar Biol Ecol 161:145-178

Underwood AJ (1997) Experiments in ecology - their logical design and interpretation using analysis of variance. Cambridge University Press, Cambridge

Winer BJ, Brown DR, Michels KM (1991) Statistical principles in experimental design. McGraw-Hill Inc, New York

Submitted: December 7, 1998; Accepted: December 2, 1999 Proofs received from author(s): May 18, 2000 